\title{
A new subspecies of Candalides geminus Edwards \& Kerr, 1978 (Lepidoptera: Lycaenidae) from the Northern Territory, Australia
}

\author{
Michael F. Braby \\ Australian National Insect Collection, National Research Collections Australia, GPO Box 1700, \\ Canberra, ACT 2601, Australia; and Division of Ecology and Evolution, Research School of Biology, \\ The Australian National University, Acton, ACT 2601, Australia
}

Email: michael.braby@anu.edu.au

\begin{abstract}
Candalides geminus gagadju ssp. nov. from the 'Top End' of the Northern Territory is described, illustrated and compared with the nominate subspecies $C$. geminus geminus Edwards \& Kerr, 1978 and C. erinus (Fabricius, 1775). It differs from C. geminus geminus by four fixed phenotypic character states, but not in genitalic morphology nor in morphology of the immature stages. The taxon is restricted to sandstone blocks in the higher rainfall areas where it is sympatric with C. erinus, narrowly sympatric with C. delospila (Waterhouse, 1903), but allopatric with C. geminus geminus from eastern Australia. Candalides geminus gagadju breeds in heathy woodland where the larval food plants (Cassytha filiformis and C. capillaris) grow as hemi-parasitic vines. Although material of the subspecies has been known in museum collections for at least 45 years (earliest collections date to October 1972), its taxonomic identity, comparative morphology, distribution and biology have remained poorly known. During 2007-2014, I conducted detailed field investigations in north-western and northern Australia to address these substantial knowledge gaps.
\end{abstract}

KEYWORDS: Candalidini, Kakadu National Park, Nesolycaena, taxonomy, Top End

urn:Isid:zoobank.org:pub:A8240497-5EEC-45C2-B6FF-513120BA2220

\section{INTRODUCTION}

The lycaenid tribe Candalidini, as circumscribed by Eliot (1973), is endemic to the Australian zoogeographic region where it is restricted to Australia and mainland New Guinea and its adjacent islands (Parsons 1998; Braby 2000). It currently contains 37 species and 23 subspecies (60 taxa) referred to two genera (Candalides Hübner, 1819 and Nesolycaena Waterhouse \& Turner, 1905), and thus represents a significant evolutionary radiation and characteristic component of the Australo-Papuan butterfly fauna. Since the revisionary work of Tite (1963), a remarkable number of new taxa have been described during the past 30 years (Parsons 1986; d'Apice and Miller 1992; Braby 1996, 2008; Williams and Bollam 2001; Tennent 2004; Braby and Douglas 2004; Müller 2013, 2014; Müller and Tennent 2016), suggesting that the taxonomic inventory of the tribe is incomplete and that additional taxa may await discovery.
As part of a broader study investigating the phylogenetic relationships and generic classification of the Candalidini, the purpose of this paper is to determine the species boundary of an isolated population of Candalides from the 'Top End' of the Northern Territory. The population was first recorded by Kikkawa and Monteith (1980) based on a small series of specimens collected from Radon Creek on the Arnhem Land plateau, and it had been assigned to the monotypic species C. geminus Edwards \& Kerr, 1978. Elsewhere, Candalides geminus is known only from eastern Australia, mainly on or west of the Great Dividing Range from Cape York Peninsula, Queensland to Barryrennie [Conimbla National Park] near Cowra, New South Wales (Edwards and Kerr 1978), where it has a patchy distribution with populations restricted to heathy woodland on sandstone outcrops (south of Laura, Queensland) or coastal sands (north of Cooktown, Queensland). Prior to this study, very little material of $C$. geminus had been collected from the 
Northern Territory (a total of 11 specimens (6 $\hat{0}, 5$ P) from 1972-2007 are held in ANIC and QM), and it was previously known only from Kakadu National Park (Common and Waterhouse 1981). More recently, Braby (2011) reported the larval food plants from two locations in Kakadu and Nitmiluk National Parks, and discovered a new location at Wongalara Station based on material collected during a Bush Blitz expedition in 2012 (Braby 2012). Critical examination and comparison of this material has revealed that it is indeed conspecific with $C$. geminus, but that the population is taxonomically distinct according to the criteria proposed by Braby et al. (2012) for subspecies delimitation.

\section{MATERIALS AND METHODS}

Between 2007 and 2014, I conducted extensive field studies in the 'Top End' of the Northern Territory. Most of the major blocks of sandstone in this region (i.e., areas of potentially suitable habitat) were searched for presence of the butterfly (adults and/or immature stages), including Keep River-Spirit Hills National Park, Judbarra/Gregory National Park, Litchfield National Park, Limmen National Park and the Arnhem Land Plateau (Kakadu National Park, Nitmiluk National Park and Wongalara Wildlife Sanctuary). Searches were also conducted in the Kimberley region of Western Australia (Mitchell Plateau, Kalumburu, King Leopold Ranges, El Questro Wilderness Park, Purnululu National Park) and in western Queensland (Boodjamulla (Lawn Hill) National Park). Vines of the larval food plants (Cassytha spp.) were searched for the immature stages (eggs and larvae), which were reared on fresh cuttings of the food plant in captivity to adulthood in plastic containers.

The male genitalia of three specimens (from Kakadu and Nitmiluk National Parks, Northern Territory) were dissected, examined and compared with two specimens of $C$. geminus from eastern Australia (16 $\mathrm{km}$ SE of Hopevale, Queensland and Pilliga National Park, New South Wales). The genitalia were examined and compared by dissecting the terminal segments of the abdomen according to the method outlined in Braby (2000).

Adult size (both sexes) was compared with the nominate subspecies based on wingspan measurements. Wingspan was measured as the straight-line distance between the apices of each forewing of correctly spread specimens (i.e., in which the dorsum was set at right angles to the body) deposited in the ANIC using a digital calliper (K11100, Kincrome $\mathrm{C})$ to an accuracy of one decimal place $(0.1 \mathrm{~mm})$. Approximately 60 specimens of each sex were sampled from the Northern Territory and across the species' geographical range in New South Wales/Queensland. For each specimen two measurements were made and an average of the two readings was taken. Franklin and Bisa (2008) have demonstrated that wingspan is positively and significantly correlated with forewing length, and thus it is a useful proxy of adult size. The wingspan data was analysed using 2-way ANOVA (with LOCATION (NT or QLD/NSW) and SEX (Male or Female) as the independent variables) to assess any differences in size between the putative taxa.

The immature stages were compared with the published descriptions of $C$. geminus given by Edwards (1980) and material reared from Davies Creek National Park, the Burra Range, Queensland and Pilliga Scrub, New South Wales by the author.

Material was examined in the following repositories:

$\begin{array}{ll}\text { ANIC: } & \begin{array}{l}\text { Australian National Insect Collection, } \\ \text { Canberra }\end{array} \\ \text { QM: } & \text { Queensland Museum, Brisbane } \\ \text { NTM: } & \begin{array}{l}\text { Museum and Art Gallery of the Northern } \\ \text { Territory, Darwin }\end{array}\end{array}$

\section{TAXONOMY}

Family Lycaenidae Leach, 1815

Subfamily Theclinae Swainson, 1831

Tribe Candalidini Eliot, 1973

Genus Candalides Hübner, 1819

Candalides Hübner, 1819: 73.

Rusticus xanthospilos Hübner, 1817 by subsequent designation of Scudder (1875).

\section{Candalides geminus \\ Edwards \& Kerr, 1978}

\section{Candalides geminus gagadju ssp. nov.}

Figures 5-8, 13, 14

urn:Isid:zoobank.org:act:50735CD9-1BE9-4AC7-A570510B0A14AA66

\section{MATERIAL EXAMINED}

Holotype

Australia: Northern Territory: $\widehat{\jmath}$ ' $12.85463^{\circ} \mathrm{S}$, $132.81677^{\circ} \mathrm{E}$, Barrk Track, Nourlangie Rock, Kakadu NP, NT, 4 MAY 2008, MF Braby \& LJ Aitchison' (ANIC). 


\section{Paratypes}

Australia: Northern Territory: 67 ๙ิ, 62 ․ 1 ๙ ' $12.31 \mathrm{~S} 132.58 \mathrm{E}, 9 \mathrm{~km} \mathrm{~N}$ by E of Mudginbarry H.S., N.T. 30 Oct. 1972, IFB. Common, E.D. Edwards, MS. Upton' (ANIC); 1 q '12.25S 132.58E, $1 \mathrm{~km}$ $\mathrm{N}$ of Cahills Crossing, East Alligator River, N.T. 31 Oct. 1972, IFB. Common, E.D. Edwards, MS. Upton' (ANIC); 1 q '12.52S 132.50E, Koongarra, $15 \mathrm{~km}$ E of Mt. Cahill, N.T., 8 Mar 1973, M.S. Upton' (ANIC); 2 q '12.50S 132.51E, $15 \mathrm{~km} \mathrm{NE}$ of Mt. Cahill, N.T., 23 May 1973, E.D. Edwards \& M.S. Upton' (ANIC); 1 đo, 1 q '12.31S 132.58E, 9km NE of Mudginbarry H.S., NT. 26 May 1973, E.D. Edwards \& M.S. Upton' (ANIC); 1 त 'N.T. 12.45S, 132.53E, Radon Ck. (openforest), 14-16 July 1979, G. Monteith \& D. Cook' (ANIC); 1 శึ ' $12.85701^{\circ} \mathrm{S}, 132.79053^{\circ} \mathrm{E}$, Nawurlandja, Kakadu NP, NT, 160m, 28 JAN. 2007, M.F. Braby', 'genitalia 024' (ANIC); 1 đ̊ ' $14.32032^{\circ} \mathrm{S}, 132.43723^{\circ} \mathrm{E}$, Windolf Trail, Katherine Gorge, Nitmiluk NP, NT, 20 JUL. 2007, MF Braby \& LJ Aitchison' (ANIC); 2 ô, 1 o ' $14.32032^{\circ} \mathrm{S}, 132.43723^{\circ} \mathrm{E}$, Windolf Trail, Katherine Gorge, Nitmiluk NP, NT, 21 JUL. 2007, MF Braby \& LJ Aitchison' (ANIC); 1 ' $14.32032^{\circ} \mathrm{S}$, $132.43723^{\circ} \mathrm{E}$, Windolf Trail, Katherine Gorge, Nitmiluk NP, NT, emg. 20 AUG. 2007, MF Braby \& LJ Aitchison', 'Reared from early instar larva on Cassytha filiformis, coll. 21 JUL. 2007, pupated 8 AUG. 2007' (ANIC); 6 ` ' $14.32032^{\circ} \mathrm{S}, 132.43723^{\circ} \mathrm{E}$, Windolf Trail, Katherine Gorge, Nitmiluk NP, NT, 16 AUG. 2007, M.F. Braby \& I. Morris' (ANIC); 1 đ ' $14.32032^{\circ} \mathrm{S}, 132.43723^{\circ} \mathrm{E}$, Windolf Trail, Katherine Gorge, Nitmiluk NP, NT, emg. 2 SEP. 2007, M.F. Braby \& I. Morris', 'Reared from larva on Cassytha filiformis, coll. 16 AUG. 2007' (ANIC); 1 त ' $14.32032^{\circ} \mathrm{S}, 132.43723^{\circ} \mathrm{E}$, Windolf Trail, Katherine Gorge, Nitmiluk NP, NT, emg. 8 SEP. 2007, M.F. Braby \& I. Morris', 'Reared from larva on Cassytha filiformis, coll. 16 AUG. 2007' (ANIC); 1 ' $14.32032^{\circ} \mathrm{S}, 132.43723^{\circ} \mathrm{E}$, Windolf Trail, Katherine Gorge, Nitmiluk NP, NT, emg. 10 SEP. 2007, M.F. Braby \& I. Morris', 'Reared from egg on Cassytha filiformis, coll. 16 AUG. 2007' (ANIC); 1 o ' $14.32032^{\circ} \mathrm{S}, 132.43723^{\circ} \mathrm{E}$, Windolf Trail, Katherine Gorge, Nitmiluk NP, NT, emg. SEP. 2007, M.F. Braby \& I. Morris' (ANIC); 5 ふै, 2 q ' $12.83696^{\circ} \mathrm{S}, 132.85626^{\circ} \mathrm{E}$, Gubara Track carpark, Kakadu NP, NT, 5 MAY 2008, MF Braby \& LJ Aitchison' (ANIC); 1 क ' $12.83696^{\circ} \mathrm{S}, 132.85626^{\circ} \mathrm{E}$, Gubara Track carpark, Kakadu NP, NT, emg. 20 MAY 2008, MF Braby \& LJ Aitchison', 'Reared from larva on Cassytha filiformis, coll. 5 MAY 2008' (ANIC); 1 q ' $12.83696^{\circ} \mathrm{S}, 132.85626^{\circ} \mathrm{E}$, Gubara Track carpark, Kakadu NP, NT, emg. 24 MAY 2008, MF Braby \& LJ Aitchison', Reared from larva on
Cassytha filiformis, coll. 5 MAY 2008' (ANIC); 3 o, 7 q ' $12.83696^{\circ} \mathrm{S}, 132.85626^{\circ} \mathrm{E}$, Gubara Track carpark, Kakadu NP, NT, 30 JAN. 2009, MF Braby \& LJ Aitchison' (ANIC); 1 ô, 5 q ' $12.83696^{\circ} \mathrm{S}$, $132.85626^{\circ} \mathrm{E}$, Gubara Track carpark, Kakadu NP, NT, 4 DEC. 2009, MF Braby \& J Armstrong' (ANIC); 1 ô ' $12.83696^{\circ} \mathrm{S}, 132.85626^{\circ} \mathrm{E}$, Gubara Track carpark, Kakadu NP, NT, emg. 22 DEC. 2009, MF Braby \& J Armstrong', 'Reared from larva on Cassytha filiformis, coll. 4 DEC. 2009, pupated 13 DEC. 2009' (ANIC); 2 ô, 1 ' $12.83696^{\circ} \mathrm{S}, 132.85626^{\circ} \mathrm{E}$, Gubara Track carpark, Kakadu NP, NT, 26 JUN. 2011, M.F. Braby' (ANIC); 1 đo ' $12.83696^{\circ} \mathrm{S}, 132.85626^{\circ} \mathrm{E}$, Gubara Track carpark, Kakadu NP, NT, emg. 14 JUL. 2011, M.F. Braby', 'Reared from larva on Cassytha filiformis, coll. 26 JUN. 2011' (ANIC); 4 ふૈ, 7 ㅇ ' $12.85463^{\circ} \mathrm{S}, 132.81677^{\circ} \mathrm{E}$, Barrk Track, Nourlangie Rock, Kakadu NP, NT, 4 MAY 2008, MF Braby \& LJ Aitchison’ (ANIC); 1 † ‘ $12.85463^{\circ} \mathrm{S}, 132.81677^{\circ} \mathrm{E}$, Barrk Track, Nourlangie Rock, Kakadu NP, NT, emg. 18 MAY 2008, MF Braby \& LJ Aitchison', 'Reared from larva on Cassytha filiformis, coll. 4 MAY 2008' (ANIC); 1 o ' $12.85463^{\circ} \mathrm{S}, 132.81677^{\circ} \mathrm{E}$, Barrk Track, Nourlangie Rock, Kakadu NP, NT, emg. 19 MAY 2008, MF Braby \& LJ Aitchison', 'Reared from larva on Cassytha filiformis, coll. 4 MAY 2008' (ANIC); 1 đo ' $12.85463^{\circ} \mathrm{S}, 132.81677^{\circ} \mathrm{E}$, Barrk Track, Nourlangie Rock, Kakadu NP, NT, emg. 3 JUN. 2008, MF Braby \& LJ Aitchison', 'Reared from egg on Cassytha filiformis, pupated 23 MAY 2008, coll. 4 MAY 2008' (ANIC); 2 ' ' $13.43089^{\circ} \mathrm{S}, 132.41837^{\circ} \mathrm{E}$, Waterfall Ck, Gunlom, Kakadu NP, NT, 28 AUG. 2008, MF Braby \& LJ Aitchison' (ANIC); 6 ふै, 10 우 ' $13.42880^{\circ} \mathrm{S}, 132.41779^{\circ} \mathrm{E}$, Waterfall Ck, Gunlom, Kakadu NP, NT, 29 AUG. 2008, MF Braby \& LJ Aitchison' (ANIC); 1 đ ' $13.42880^{\circ} \mathrm{S}, 132.41779^{\circ} \mathrm{E}$, Waterfall Ck, Gunlom, Kakadu NP, NT, emg. 22 SEP. 2008, MF Braby \& LJ Aitchison', 'Reared from instar I on Cassytha filiformis, coll. 29 AUG. 2008' (ANIC); 3 o, 1 o ' $12.84375^{\circ} \mathrm{S}, 132.82558^{\circ} \mathrm{E}, 1 \mathrm{~km}$ ENE Nanguluwur, Kakadu NP, NT, 50 m, 31 JAN. 2009, MF Braby \& LJ Aitchison' (ANIC); 1 ` ‘ $12.84375^{\circ} \mathrm{S}$, $132.82558^{\circ} \mathrm{E}, 1 \mathrm{~km}$ ENE Nanguluwur, Kakadu NP, NT, 50 m, emg. 13 FEB. 2009, MF Braby \& LJ Aitchison', 'Reared from larva on Cassytha filiformis, coll. 31 JAN. 2009' (ANIC); 1 q ' $12.84375^{\circ} \mathrm{S}$, $132.82558^{\circ} \mathrm{E}, 1 \mathrm{~km}$ ENE Nanguluwur, Kakadu NP, NT, 50 m, emg. 14 FEB. 2009, MF Braby \& LJ Aitchison', 'Reared from larva on Cassytha filiformis, coll. 31 JAN. 2009' (ANIC); 1 q ' $12.84375^{\circ} \mathrm{S}$, $132.82558^{\circ} \mathrm{E}, 1 \mathrm{~km}$ ENE Nanguluwur, Kakadu NP, NT, 50 m, emg. 15 FEB. 2009, MF Braby \& LJ Aitchison', 'Reared from larva on Cassytha filiformis, coll. 31 JAN. 2009' (ANIC); 1 đ’, 1 ㅇ ‘ $12.84375^{\circ} \mathrm{S}$, $132.82558^{\circ} \mathrm{E}, 1 \mathrm{~km}$ ENE Nanguluwur, Nourlangie 
Rock, NT, 8 NOV. 2009, M.F. Braby' (ANIC); 1 ઈ ' $12.84375^{\circ} \mathrm{S}, 132.82558^{\circ} \mathrm{E}, 1 \mathrm{~km}$ ENE Nanguluwur, Nourlangie Rock, NT, emg. 22 NOV. 2009, M.F. Braby', 'Reared from larva on Cassytha filiformis, coll. 8 NOV. 2009' (ANIC); 1 क ' $12.84650^{\circ} \mathrm{S}$, $132.82295^{\circ} \mathrm{E}$, Nourlangie Rock, Kakadu NP, NT, 120 m, 1 FEB. 2009, M.F. Braby \& LJ Aitchison' (ANIC); 1 ก ' $12.84650^{\circ} \mathrm{S}, 132.82295^{\circ} \mathrm{E}$, Nourlangie Rock, Kakadu NP, NT, 120 m, 8 NOV. 2009, M.F. Braby' (ANIC); 1 q ' $12.84650^{\circ} \mathrm{S}, 132.82295^{\circ} \mathrm{E}$, Nourlangie Rock, Kakadu NP, NT, emg. 9 FEB. 2014, MF Braby \& LJ Aitchison', 'Reared from larva on Cassytha filiformis, coll. 26 JAN. 2014' (ANIC); 1 त, 1 ㅇ ' $12.84650^{\circ} \mathrm{S}, 132.82295^{\circ} \mathrm{E}, 0.6 \mathrm{~km}$ E Nanguluwur, Kakadu NP, NT, 120m, 5 DEC. 2009, MF Braby \& J

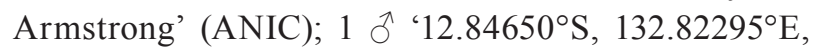
$0.6 \mathrm{~km}$ E Nanguluwur, Kakadu NP, NT, $120 \mathrm{~m}, 5$ DEC. 2009, MF Braby \& J Armstrong', 'genitalia 051' (ANIC); 2 우 ' $12.84650^{\circ} \mathrm{S}, 132.82295^{\circ} \mathrm{E}, 0.6$ km E Nanguluwur, Kakadu NP, NT, 120m, 7 DEC. 2009, MF Braby \& J Armstrong' (ANIC); 1 $' 12.84650^{\circ} \mathrm{S}, 132.82295^{\circ} \mathrm{E}, 0.6 \mathrm{~km}$ E Nanguluwur, Kakadu NP, NT, 15 FEB. 2013, MF Braby' (ANIC); 1 ㅇ ' $12.83721^{\circ} \mathrm{S}, 132.84970^{\circ} \mathrm{E}, 0.6 \mathrm{~km}$ W Gubara Tk carprk, Kakadu NP, NT, 16 OCT. 2010, M.F. Braby \& S. Keates' (ANIC); 1 q ' $12.83721^{\circ} \mathrm{S}$, $132.84970^{\circ} \mathrm{E}, 0.6 \mathrm{~km} \mathrm{~W}$ Gubara Tk carprk, Kakadu NP, NT, emg. 26 NOV. 2010, M.F. Braby', 'Reared from larva on Cassytha filiformis, coll. 12 NOV. 2010’ (ANIC); 1 q ' $13.20353^{\circ} \mathrm{S}, 130.71574^{\circ} \mathrm{E}$, Tolmer Falls, Litchfield NP, NT, 28 APR. 2011, MF Braby \& JJ Armstrong' (ANIC); 4 กै, 2 ㅇ ' $13.19495^{\circ} \mathrm{S}$, $130.70848^{\circ} \mathrm{E}, 1 \mathrm{~km} \mathrm{NW}$ of Tolmer Falls, Litchfield NP, NT, 9 JUL. 2011, M.F. Braby \& S. Keates' (ANIC); 1 के ' $13.19495^{\circ} \mathrm{S}, 130.70848^{\circ} \mathrm{E}, 1 \mathrm{~km} \mathrm{NW}$ of Tolmer Falls, Litchfield NP, NT, emg. 11 AUG. 2011, M.F. Braby \& S. Keates', 'Reared from egg on Cassytha capillaris, coll. 9 JUL. 2011' (ANIC); 1
' $13.19495^{\circ} \mathrm{S}, 130.70848^{\circ} \mathrm{E}, 1 \mathrm{~km} \mathrm{NW}$ of Tolmer Falls, Litchfield NP, NT, emg. 12 AUG. 2011, M.F. Braby \& S. Keates', 'Reared from egg on Cassytha capillaris, coll. 9 JUL. 2011' (ANIC); 3 o ' $14.25149^{\circ} \mathrm{S}$, $134.46429^{\circ} \mathrm{E}, 12 \mathrm{~km} \mathrm{~S}$ of H/S Wongalara WS, NT, 29 MAY 2012, M.F. Braby \& R. Leijs' (ANIC); 1 ㅇ ' $14.25149^{\circ} \mathrm{S}, 134.46429^{\circ} \mathrm{E}, 12 \mathrm{~km} \mathrm{~S}$ of H/S Wongalara WS, NT, 29 MAY 2012, M.F. Braby \& R. Leijs' (NTM); $1 \delta^{\lambda}$ ' $14.25149^{\circ} \mathrm{S}, 134.46429^{\circ} \mathrm{E}, 12 \mathrm{~km} \mathrm{~S}$ of H/S Wongalara WS, NT, 5 JUN. 2012, M.F. Braby' (NTM); 4 `, 1 q ' $14.25149^{\circ} \mathrm{S}, 134.46429^{\circ} \mathrm{E}, 12 \mathrm{~km} \mathrm{~S}$ of H/S Wongalara WS, NT, 5 JUN. 2012, M.F. Braby' (ANIC); 1 o ' $14.16221^{\circ} \mathrm{S}, 134.12724^{\circ} \mathrm{E}$, Mt Throsby, Wongalara WS, NT, emg. 26 JUN. 2012, M.F. Braby', 'Reared from larva on Cassytha filiformis, coll. 30 MAY 2012' (ANIC); 1 q ' $14.16221^{\circ} \mathrm{S}, 134.12724^{\circ} \mathrm{E}$, Mt Throsby, Wongalara WS, NT, emg. 14 JUL. 2012, M.F. Braby', 'Reared from egg on Cassytha filiformis, coll. 30 MAY 2012' (ANIC).

\section{Other material}

Australia: Northern Territory: $3 \hat{\text { ते }}$ N.T. 12.45S, 132.53E, Radon Ck. (openforest), 14-16 July 1979, G. Monteith \& D. Cook' (QM); 1 i ' $13^{\circ} 25^{\prime} 43^{\prime} \mathrm{S}$, $132^{\circ} 25^{\prime} 06^{\prime}$ E, Gunlom, Kakadu NP, NT, 6 MAY 2007, L. Reid' (ANIC); 2 ` ' $14.32032^{\circ} \mathrm{S}, 132.43723^{\circ} \mathrm{E}$, Windolf Trail, Katherine Gorge, Nitmiluk NP, NT, 16 AUG. 2007, M.F. Braby \& I. Morris' (ANIC); 3 ㅇ ' $14.32032^{\circ} \mathrm{S}, 132.43723^{\circ} \mathrm{E}$, Windolf Trail, Katherine Gorge, Nitmiluk NP, NT, 20 JUL. 2007, MF Braby \& LJ Aitchison' (ANIC); 1 ` ' $14.32032^{\circ} \mathrm{S}, 132.43723^{\circ} \mathrm{E}$, Windolf Trail, Katherine Gorge, Nitmiluk NP, NT, 20 JUL. 2007, MF Braby \& LJ Aitchison', 'genitalia 039' (ANIC); $1 \delta^{\lambda} ' 14.32032^{\circ} \mathrm{S}, 132.43723^{\circ} \mathrm{E}$, Windolf Trail, Katherine Gorge, Nitmiluk NP, NT, 21 JUL. 2007, MF Braby \& LJ Aitchison' (ANIC); 1 ` ' $12.85463^{\circ} \mathrm{S}$, $132.81677^{\circ} \mathrm{E}$, Barrk Track, Nourlangie Rock, Kakadu NP, NT, 4 MAY 2008, MF Braby \& LJ Aitchison' (ANIC); 1 i ' $13.20353^{\circ} \mathrm{S}, 130.71574^{\circ} \mathrm{E}$, Tolmer Falls,

TABLE $1 \quad$ Wingspan measurements for Candalides geminus subspecies. Two-way ANOVA (with LOCATION and SEX as the independent variables) revealed significant differences in wing size between the two taxa $(F=454.3, d f=$ 235, $P<0.0001)$, but no differences between the sexes within each subspecies $(P>0.01)$.

\begin{tabular}{llllll} 
Subspecies & Location & Sex & Range & Mean \pm SD & $\mathrm{n}$ \\
\hline C. g. gagadju & $\mathrm{NT}$ & male & $17.6-24.8$ & $21.19 \pm 1.455$ & 60 \\
C. g. gagadju & $\mathrm{NT}$ & female & $18.2-24.6$ & $21.72 \pm 1.459$ & 57 \\
C. g. geminus & QLD/NSW & male & $22.2-28.9$ & $25.27 \pm 1.488$ & 60 \\
C. g. geminus & QLD/NSW & female & $22.1-31.2$ & $25.92 \pm 1.487$ & 60 \\
\hline
\end{tabular}


Litchfield NP, NT, 28 APR. 2011, MF Braby \& JJ Armstrong' (ANIC); 1 ` '13.19495 ${ }^{\circ} \mathrm{S}, 130.70848^{\circ} \mathrm{E}$, $1 \mathrm{~km} \mathrm{NW}$ of Tolmer Falls, Litchfield NP, NT, 9 JUL. 2011, M.F. Braby \& S. Keates’ (ANIC).

\section{DIAGNOSIS}

Candalides geminus gagadju (Figures 5-8) differs from the nominate subspecies $C$. geminus geminus (Figures 1-4) by the following four phenotypic characters: (1) adults are significantly smaller in size (Table 1); (2) the termen of the wings, particularly the forewing, is more rounded with the apex less sharply pointed, especially males; (3) the upperside colour of females is uniformly dark grey-brown with the basal and central iridescent purple areas either absent
( $50 \%$ of specimens examined, $n=60$ ) or substantially reduced to two small subterminal 'patches' of purple scales on the hindwing (between veins $\mathrm{CuA}_{1}$ and $1 \mathrm{~A}+2 \mathrm{~A}$ ), whereas in $C$. geminus geminus the purple area, although variable in extent, is always present and far more extensive; and (4) the shape described by the postmedian line of spots on the underside of the hindwing is both generally more concave and displaced distally towards the subterminal line of spots so that the postmedian band (the intervening area between these two lines) is narrower and often a paler grey compared to the rest of the underside ground colour. The underside ground colour of $C$. geminus gagadju, like that of $C$. geminus geminus, is grey, although populations of $C$. geminus geminus from the southern
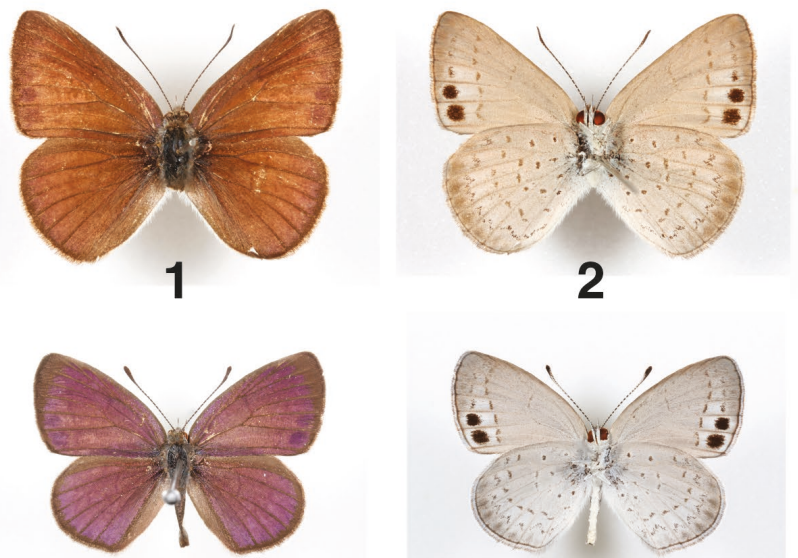

5
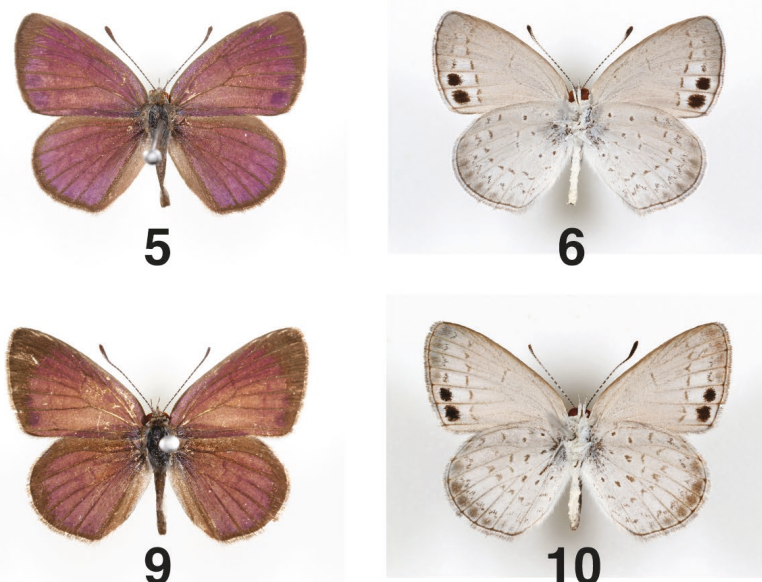

6

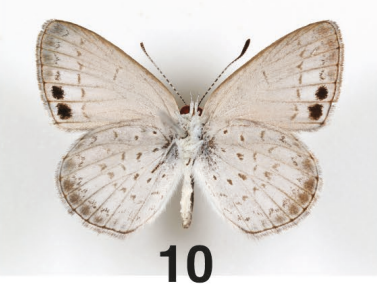

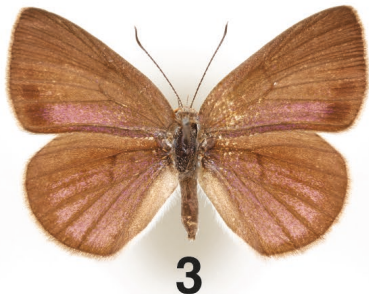
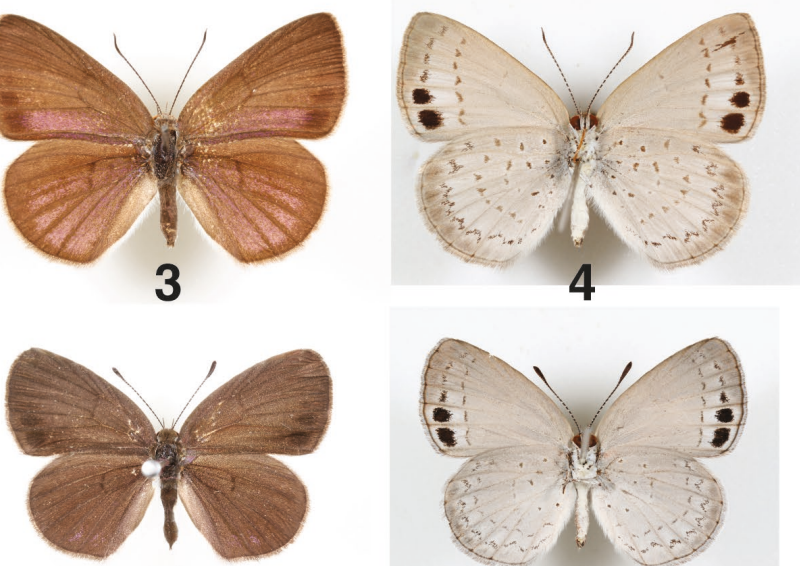

7

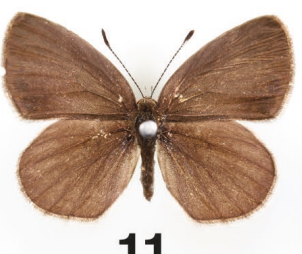

11
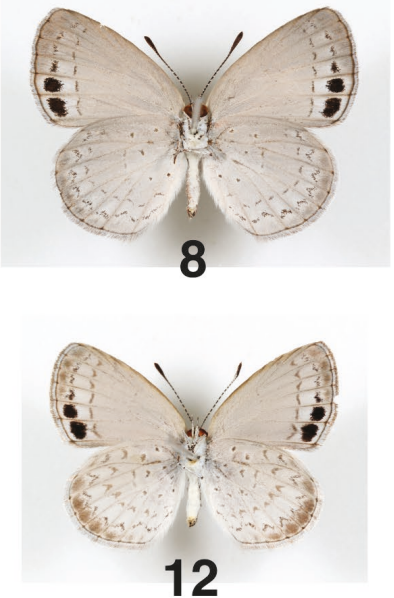

$10 \mathrm{~mm}$

FIGURES 1-12

Adult specimens of Candalides spp. 1, 2, C. geminus geminus holotype male showing dorsal and ventral views [labelled 'Captain Billy Creek, Cape York Pen, N. Old, 14250E, 1145S, 12-14.vii.1975, J.F.R. Kerr', 'Genitalia Slide M347' (ANIC)]; 3, 4, C. geminus geminus paratype female showing dorsal and ventral views [labelled same as holotype (ANIC)]; 5, 6, C. geminus gagadju ssp. nov. male holotype showing dorsal and ventral views [labelled '12.85463ㅇ, $132.81677^{\circ} \mathrm{E}$, Barrk Track, Nourlangie Rock, Kakadu NP, NT, 4 MAY 2008, MF Braby \& LJ Aitchison' (ANIC)]; 7, C. geminus gagadju paratype female dorsal view [labeled '12.83696 S, $132.85626^{\circ} \mathrm{E}$, Gubara Track carpark, Kakadu NP, NT, emg. 24 MAY 2008, MF Braby \& LJ Aitchison, Reared from larva on Cassytha filiformis, coll. 5 MAY 2008' (ANIC)]; 8, C. geminus gagadju paratype female ventral view [labelled ' $12.84375^{\circ} \mathrm{S}, 132.82558^{\circ} \mathrm{E}, 1 \mathrm{~km} \mathrm{ENE}$ Nanguluwur, Nourlangie Rock, NT, 8 NOV. 2009, M.F. Braby' (ANIC)]; 9, 10, C. erinus erinus male showing dorsal and ventral views [labelled ' $12.85930^{\circ} \mathrm{S}, 132.81754^{\circ} \mathrm{E}$, Nourlangie Rock, Kakadu NP, NT, 4 MAY 2008, MF Braby \& LJ Aitchison, MFB Collection 00369' (ANIC)]; 11, 12, C. erinus erinus female showing dorsal and ventral views [labelled '12.29586, $136.90302^{\circ} \mathrm{E}$, Rocky Bay, Gove Peninsula, NT, 1 SEP. 2007, M.F. Braby, MFB Collection 00369' (ANIC)]. 

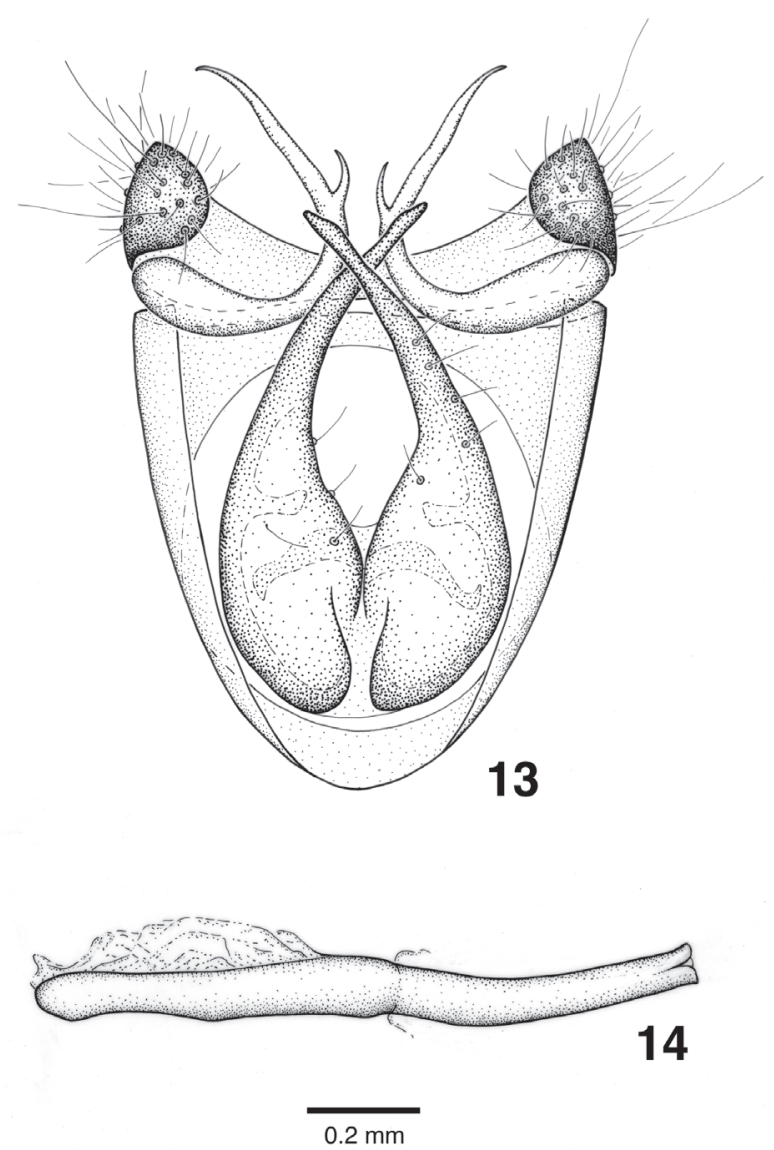

FIGURES 13-14 Male genitalia of Candalides geminus gagadju ssp. nov. 13, posterior view showing valvae and brachia, with phallus removed; 14 , phallus, lateral view.

end of the range (Pilliga Scrub, Warrumbungle Ranges, and near Dubbo, New South Wales) differ in having the colour dark brownish-grey with the underside markings less distinct and the terminal blotches on the hindwing absent.

In many respects, C. geminus gagadju more closely resembles C. erinus (Fabricius, 1775) (Figures 9-12) from northern Australia in size, shape and colour pattern than C. geminus geminus. However, in $C$. erinus the postmedian band and dark grey terminal blotches on the underside of the hindwing are more distinct. In $C$. erinus, the postmedian band is both broader, with a straighter inner edge, and paler so that it contrasts against the grey ground colour, whereas in C. geminus gagadju the postmedian band is narrower, with the inner edge distinctly curved, and less contrasted. In males, the black terminal band or margin on the upperside of the forewing is broader towards the apex in C. erinus, whereas in $C$. geminus gagadju the band is narrower and even in width parallel to the termen. Also, the male genitalia of C. geminus gagadju (Figures 13-14) differ considerably from C. erinus, but are typical of C. geminus in which the valvae gradually taper towards the apex (see comparative illustrations in Edwards and Kerr 1978, p. 85). In C. erinus, the valvae are very and long slender and do not taper from the swollen base.

\section{DESCRIPTION}

Male. Forewing length $12.4 \mathrm{~mm}$ (holotype, Figures 5-6), range 10.5-14.4 mm. Upperside colour purplishbronze, with narrow black margins. Underside ground colour pale grey, with a series of small darker grey spots and markings; forewing with a postmedian line of spots extending from costa to dorsum, a line of three subterminal spots from costa to vein $M_{3}$, an obscure black subterminal spot between veins $M_{3}$ and $\mathrm{CuA}_{1}$, and two larger prominent black subterminal spots near tornus between veins $\mathrm{CuA}_{1}$ and $1 \mathrm{~A}+2 \mathrm{~A}$, each surrounded by a pale grey-white area that extends proximally to postmedian line; hindwing with a narrow paler postmedian band edged proximally by a series of darker spots and distally by a subterminal series of spots, followed by a series of larger obscure dark grey terminal blotches.

Female. Forewing length $12.6-14.1 \mathrm{~mm}$ (paratypes, Figures 7-8), range 10.8-14.6 mm. Upperside brownblack; forewing with two black subterminal spots near tornus; hindwing often with two small purple subterminal patches between veins $\mathrm{CuA}_{1}$ and $1 \mathrm{~A}+2 \mathrm{~A}$. Underside colour and pattern similar to male.

\section{VARIATION}

In males, the upperside colour varies from dull bronze-purple to shining purple, with examples of the latter form collected or reared mainly during the cooler dry season months (May-August) suggesting that there may be a seasonal component to the variation.

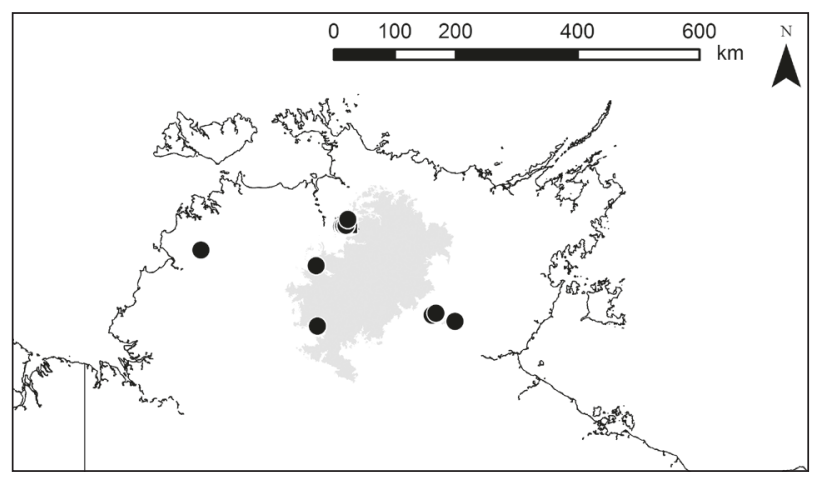

FIGURE 15 Distribution of Candalides geminus gagadju in the Top End of the Northern Territory. Grey shaded polygon shows extent of the Arnhem Land plateau. 

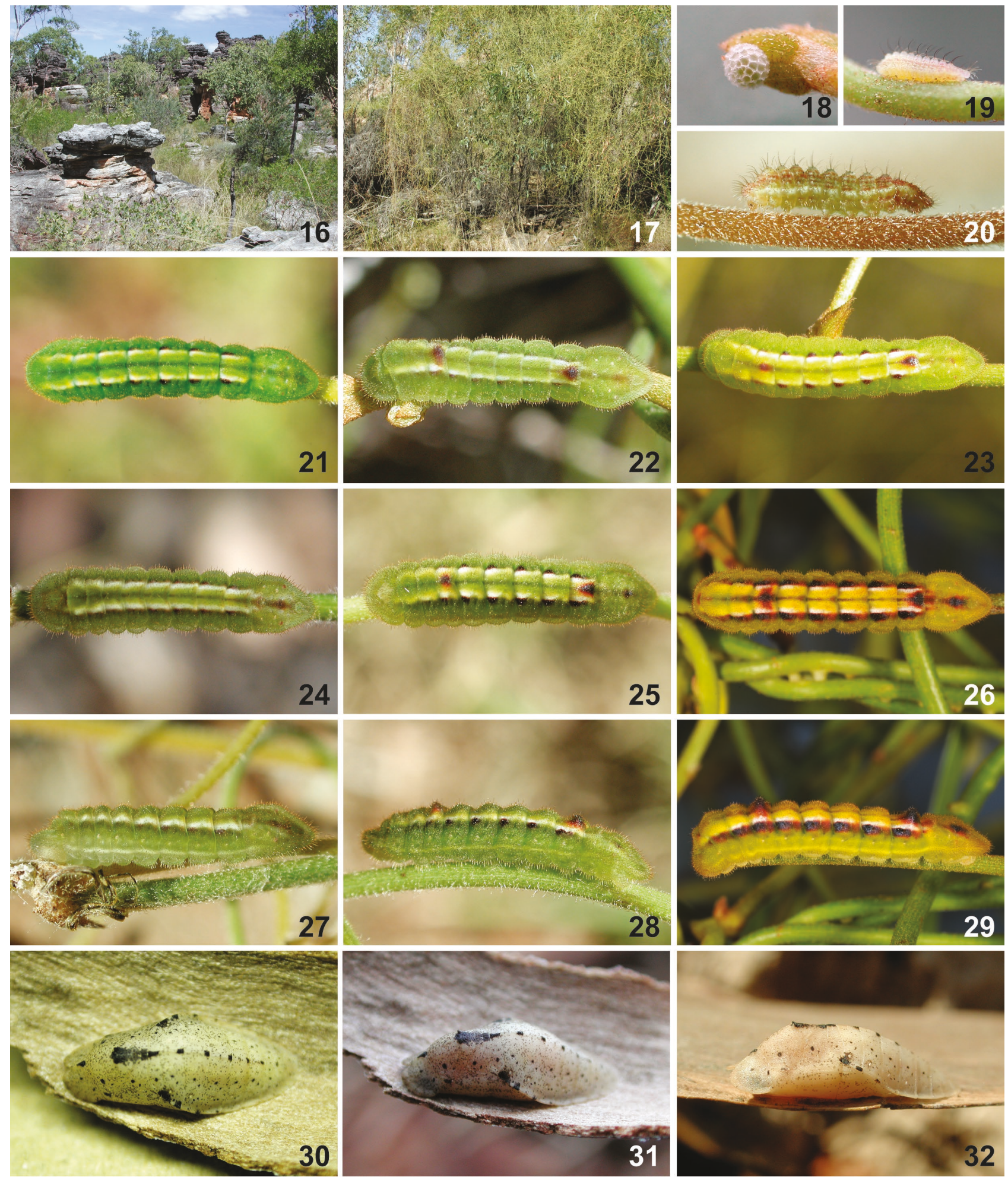

FIGURES 16-32 Life history of Candalides geminus gagadju. 16, eucalypt heathy open-woodland habitat on broken sandstone at Nourlangie Rock, Kakadu National Park; 17, larval food plant Cassytha filiformis at Windolf Trail, Nitmiluk (Katherine Gorge) National Park; 18, egg; 19, first instar larva; 20, second instar larva; 21-29, final instar larva, showing phenotypic variation, 21-26, dorsal view, 27-29, lateral view; 30-32, pupa, showing dorsal, dorsolateral and lateral views. 
The width of the black margin also varies. In females, the extent of the purple iridescent areas varies: when present, it is usually restricted to the subterminal region of the hindwing (comprising two small patches), but in cell $1 \mathrm{~A}+2 \mathrm{~A}$ it may extend towards the base, and occasionally a third subterminal patch occurs between veins $\mathrm{M}_{3}$ and $\mathrm{Cu} \mathrm{A}_{1}$; very occasionally there may be a dusting of purple scales at the base of the forewing, usually just above the dorsum. In both sexes, there is considerable variation in the extent and clarity of the underside markings, particularly the postmedian and subterminal series of spots, which may be very obscure in some specimens.

\section{REMARKS}

Edwards and Kerr (1978) described and illustrated C. geminus, which had previously been confused with the closely-related $C$. hyacinthinus (Semper), as a monotypic species from eastern Australia, with type locality Captain Billy Creek, Cape York Peninsula, Queensland. However, material from the Top End of the Northern Territory was not included in their description and diagnosis. Although specimens of C. geminus gagadju (2 ô, 5 i in ANIC) were first collected from western Arnhem Land in 1972-73 by I.F.B. Common, E.D. Edwards and M.S. Upton, this material was not considered in the description and distribution of $C$. geminus because it had been misidentified and confused with $C$. erinus (E.D. Edwards, pers. comm., 2017). The first published record of $C$. geminus from the Top End was the report by Kikkawa and Monteith (1980), who recorded the species based on a small series ( $4 \delta$ in QM and ANIC) from Radon Creek on the Arnhem Land plateau in 1979.

The systematic relationships of the $C$. erinus species group have not been established, but a preliminary molecular phylogenetic analysis of the Candalidini indicates that $C$. geminus and $C$. erinus are sister taxa and are genetically divergent by $2.7 \%$ for mitochondrial COI (24 bp differences out of $880 \mathrm{bp}$ for the barcode region) under the HKY substitution model, whereas the distance between the two subspecies of $C$. geminus for this region is $1.7 \%$ or 15 bp (M. Espeland and M.F. Braby, unpublished data).

\section{ETYMOLOGY}

The name Gagadju is the language name for the Australian Aboriginal tribe from western Arnhem Land in the Northern Territory where this butterfly is predominantly distributed. The name has several variations in spelling (e.g. Gagadu, Kakadju, Kakadu and Kakatu), but Gagadju is the name adopted here. It is intended as a noun in apposition.

\section{DISTRIBUTION}

Candalides geminus gagadju is endemic to the Top End of the Northern Territory where it has been recorded from Litchfield National Park (Tolmer Falls area), Kakadu National Park (including Nourlangie Rock and Gunlom), Nitmiluk (Katherine Gorge) National Park and Wongalara Wildlife Sanctuary. The distribution is centred mainly on the Arnhem Land plateau (Figure 15), although there is a disjunct population $200 \mathrm{~km}$ further west in Litchfield National Park. Searches for the taxon in the sandstone areas of the Kimberley region of Western Australia, Keep River-Spirit Hills, Judbarra/ Gregory and Limmen national parks in the Northern Territory, and Boodjamulla (Lawn Hill) National Park in western Queensland by the author, did not detect the subspecies. Candalides geminus gagadju frequently occurs in sympatry with $C$. erinus, and at Wongalara Wildlife Sanctuary (12 $\mathrm{km} \mathrm{S}$ of the homestead) it was recorded in sympatry with both $C$. erinus and $C$. delospila (Waterhouse, 1903).

\section{BIOLOGY}

Candalides geminus gagadju is restricted to blocks of sandstone in the higher rainfall areas $(>900 \mathrm{~mm}$ mean annual rainfall) of the Northern Territory where it breeds in eucalypt heathy woodland and open-woodland with a spinifex understorey on rocky sandstone outcrops, escarpments and plateaus where the larval food plants grow as scrambling parasitic vines in the understorey (Figures 16-17) (Braby 2011). The usual larval food plant is Cassytha filiformis L. (Lauraceae), but C. capillaris Meisn. is also used where it is present (Braby 2011). Adults have been recorded during most months of the year, but they appear to be more abundant during the wet season (NovemberJanuary) and in the mid dry season (July).

The immature stages (egg, larva and pupa) (Figures 18-32) are identical to those of C. geminus geminus, which were described by Edwards (1980). A feature distinguishing $C$. geminus from other Candalides spp. is the colour pattern of the final instar larva, which is characterised by a prominent white subdorsal line on abdominal segments 1 to 6 that is bordered laterally by a deep purple line, and the presence of two raised, red dorsal projections, on abdominal segments 1 and 6. The white subdorsal line extends to the mesothorax and metathorax, where it usually becomes pale yellow, and on the abdomen it may become yellow towards the rear of each segment. Larvae of $C$. geminus gagadju (Figures 21-29) possess these two characters, but they are highly variable in colour pattern, particularly with respect to the overall ground colour (which comprises various shades of green); the presence of the raised, red dorsal projections on abdominal segments 1 and 6 
(the projections are usually present, but occasionally both may be absent, Figures 21, 24, 27); and the extent and clarity of the purple subdorsal line, which may comprise a continuous narrow band (Figures $22,24,27$ ), a broken band of discrete spots (Figures $21,23,25,28)$, or a continuous broad band edged posteriorly with bright red (Figures 26, 29). The immature stages have been recorded in most months of the year. The life cycle is completed relatively quickly (approximately one month, with the larval duration varying from 14-18 days and pupal duration 11-12 days), indicating that breeding occurs continuously and that several generations are completed annually.

\section{ACKNOWLEDGEMENTS}

I am grateful to L.J. Aitchison, J.J. Armstrong, S. Keates and I. Morris for assistance with field work, E.D. Edwards and M. Espeland for unpublished information, S. Wright for loan of material in the QM, M. Osterkamp for preparing the scientific line drawing of the male genitalia, Y.N. Su for preparing digital illustrations of type material of Candalides geminus in the ANIC, and M.R. Williams for comments on the manuscript. Specimens from Kakadu National Park were collected under scientific research permit numbers RK 704 and RK 729. This work was supported through funding from the Australian Government's Australian Biological Resources Study (ABRS) Bush Blitz Strategic Taxonomy Grants Scheme for a project entitled 'Taxonomic revision of Candalides and allied genera in the tribe Candalidini (Lepidoptera: Lycaenidae)'. The ABRS Bush Blitz program is also gratefully acknowledged for provision of funds for field expeditions to Wongalara Wildlife Sanctuary in 2012.

\section{REFERENCES}

Braby, M.F. (1996). A new species of Nesolycaena Waterhouse and Turner (Lepidoptera: Lycaenidae) from northeastern Australia. Australian Journal of Entomology 35: 9-17.

Braby, M.F. (2000). Butterflies of Australia. Their Identification, Biology and Distribution. CSIRO Publishing: Collingwood, Melbourne.

Braby, M.F. (2008). Taxonomic review of Candalides absimilis (C. Felder, 1862) and C. margarita (Semper, 1879) (Lepidoptera: Lycaenidae), with descriptions of two new subspecies. The Beagle, Records of the Museums and Art Galleries of the Northern Territory 24: $33-54$.

Braby, M.F. (2011). New larval food plant associations for some butterflies and diurnal moths (Lepidoptera) from the Northern Territory and eastern Kimberley, Australia.
The Beagle, Records of the Museums and Art Galleries of the Northern Territory 27: 85-105.

Braby, M.F. (2012). Butterflies and diurnal moths of Wongalara Station. Final Report to Department of Sustainability, Environment, Water and Communities. Department of Land Resource Management: Darwin.

Braby, M.F. and Douglas, F. (2004). The taxonomy, ecology and conservation status of the Golden-rayed Blue, a threatened butterfly endemic to western Victoria, Australia. Biological Journal of the Linnean Society 81: 275-299.

Braby, M.F., Eastwood, R.G. and Murray, N. (2012). The subspecies concept in butterflies: has its application in taxonomy and conservation biology outlived its usefulness? Biological Journal of the Linnean Society 106: 699-716.

Common, I.F.B. and Waterhouse, D.F. (1981). Butterflies of Australia. Angus and Robertson: Sydney.

d'Apice, J.W.C. and Miller, C.G. (1992). The genus Nesolycaena Waterhouse and Turner (Lepidoptera: Lycaenidae) with a description of a new species. Australian Entomological Magazine 19: 75-80.

Edwards, E.D. (1980). The early stages of Adaluma urumelia Tindale and Candalides geminus Edwards and Kerr (Lepidoptera: Lycaenidae). Australian Entomological Magazine 7: 17-20.

Edwards, E.D. and Kerr, J.F.R. (1978). A new species of Candalides from eastern Australia and notes on Candalides hyacinthinus (Semper) (Lepidoptera: Lycaenidae). Australian Entomological Magazine 4: 81-90.

Eliot, J.N. (1973). The higher classification of the Lycaenidae (Lepidoptera): a tentative arrangement. Bulletin of the British Museum (Natural History) Entomology 28: 371-505.

Franklin, D.C. and Bisa, D. (2008). Field key to the lycaenid butterflies of the Top End and Kimberley. Northern Territory Naturalist 20: 1-18.

Kikkawa, J. and Monteith, G.B. (1980). Animal ecology of monsoon forests of the Kakadu region, Northern Territory. Queensland Museum consultancy report to Director, Australian National Parks and Wildlife Service: Canberra.

Müller, C.J. (2013). A remarkable new species of Candalides Hübner, 1819 (Lepidoptera, Lycaenidae) from the Bismarck Archipelago, Papua New Guinea. Nachrichten des Entomologischen Vereins Apollo 34: 69-72.

Müller, C.J. (2014). A new species of Candalides Hübner, 1819 from Mainland Papua New Guinea (Lepidoptera: Lycaenidae). Nachrichten des Entomologischen Vereins Apollo 35: 214-216.

Müller, C.J. and Tennent, W.J. (2016). Two new species of Candalides Hübner, 1819 (Lepidoptera: Lycaenidae) from Papua New Guinea and Indonesia. Tropical Lepidoptera 26: $25-31$.

Parsons, M.J. (1986). A new genus and twenty-six new species of butterflies (Lepidoptera: Hesperiidae, Lycaenidae, Nymphalidae) from Papua New Guinea and Irian Jaya. Tyô to Ga 37: 103-177. 
Parsons, M.J. (1998). The Butterflies of Papua New Guinea. Their Systematics and Biology. Academic Press: London.

Tennent, W.J. (2004). A new Candalides (Lepidoptera, Lycaenidae) from the D'Entrecasteux island group (Papua New Guinea). Futao 49: 2-3.

Tite, G.E. (1963). A revision of the genus Candalides and allied genera (Lepidoptera: Lycaenidae). Bulletin of the British Museum (Natural History) Entomology 14: 197-259.

Williams, M.R. and Bollam, H.H. (2001). A new subspecies of Candalides hyacinthinus (Semper) (Lepidoptera: Lycaenidae) from Western Australia. The Australian Entomologist 28: 49-54.

MANUSCRIPT RECEIVED 4 SEPTEMBER 2017; ACCEPTED 23 OCTOBER 2017. 